\title{
Legal aspects of protection of intellectual property objects in mining engineering
}

\author{
Ievgeniia Bulat ${ }^{1, *}$ \\ ${ }^{1}$ Prydneprovsk Scientific Center of National Academy of Science of Ukraine, 49000, Dnipro, \\ Simferopolska Str., 15, Ukraine
}

\begin{abstract}
The innovative model of development of Ukraine requires implementation of measures aimed at stimulation and protection of intellectual property objects and development of such improved legislative basis in this sphere that would allow not only to preserve existing scientific potential but also to ensure proper protection of the rights of creators of such objects with possibility of their further commercialization. The necessity and expediency of introducing this legal protection improvement is shown on the example of such objects as scientific discoveries in mining engineering, business methods and innovative proposals. The article is devoted to the improvement of mechanism for legal protection of intellectual property rights to the intellectual activity results in context of integration processes that take place in Ukraine. A unified approach is proposed, which assumes revealing in practical part of each claimed object its protectable part, followed by procedure of patenting in accordance with the procedure stipulated by the current legislation.
\end{abstract}

\section{Introduction}

Dynamic development of the world economy is based on innovation processes. The events taking place today in society are caused, to a considerable degree, by rapid innovative development almost in all spheres of public relations. Experience of other countries shows that improvement of legal protection of intellectual property objects and commercialization of intellectual activity results as an integral part of innovative development are still a live problem in the sphere of intellectual property. Leaving the aspect of improving legal protection of relevant intellectual investment without due regard factually makes the rights of the creators of such objects unprotected; besides, the state suffers losses due to the uncontrolled leakage of valuable scientific and technical information to abroad, hence, affecting the economy and leading significantly reduced competitiveness of the country. Social relations in terms of protection of intellectual property rights to scientific and creative developments are not properly regulated. Along with this, imperfection of the intellectual property laws regarding some objects creates barriers for investments into the science and researches, due to which almost a fifth part of our scientific and intellectual potential have to work abroad.

\footnotetext{
*Corresponding author: aasdbulat@gmail.com
} 
At the same time, one of the basic tasks of innovative development of Ukraine in the field of research activities is its integration into the European research domain, which is facilitated by the active cooperation with the European Union. On September 1, 2017, the Association Agreement between Ukraine and the European Union came into force, which, among other things, resulted in the integration of Ukraine into the European economic space, strengthening its innovation orientation, its rapid innovative development, and increasing its competitiveness. One of the priority directions under the Association Agreement is adaptation of Ukrainian legislation to the norms and standards of the European Union followed by reappraisal of experience and knowledge associated with commercialization of the innovations at the world level, and application of new approaches to their regulation at the legislative level. After all, scientific and technical potential is the basis for the globalization of the innovation sphere, and needs proper legal regulations.

Accordingly, a task that requires an urgent solution is the need to involve legal instruments developed by the civil science into improving the regulation of innovation processes and innovative development in line with the current standards of European policy in the field of creating of innovation union and open science. To this end, there are different framework programs for financing various researches and projects in the European countries. This is confirmed by implementation of the Horizon-2020 European Union Framework Program for Researches and Innovations, which Ukraine has joined, and which enable our country to actively cooperate with the European Union in the innovation field.

The aforementioned directions of scientific and innovative development of Ukraine put new challenges for domestic civil science, which should provide a proper legal mechanism in order to ensure up-to-date quality level for legal protection of the results of intellectual and creative activity. In other words, the level, which would meet European standards and would ensure a gradual and sustainable development of Ukraine in all spheres including scientific and technological activities.

At the same time, despite a certain number of scientific developments available today, the problem outlined in this article has not been properly disclosed.

\section{Methodology}

For better understanding prerequisites for improving legal protection of certain results of intellectual activity, we consider it necessary to refer to the retrospective historical and legal experience in the field of legal protection of intellectual property.

At the international normative level, the concept of "intellectual property" was established in 1967 at the Stockholm Diplomatic Convention, which created the World Intellectual Property Organization; during the Convention, objects of intellectual property were defined and further secured by the law.

According to the provisions of this Convention (Article 2, paragraph VIII), the "intellectual property" meant the rights related to:

- inventions in all areas of human activity;

- $\quad$ scientific discoveries;

- $\quad$ industrial prototypes;

- $\quad$ trademarks, service marks, trade names and commercial designations;

- $\quad$ literary, artistic and scientific works;

- $\quad$ performances of artists, recordings, radio and television programs;

- protection against unfair competition, as well as all other rights related to intellectual activity in the production, scientific, literary and artistic industries [1].

Consequently, the Convention recognized all rights to the results of intellectual activity, including scientific discoveries and others related to intellectual activity in the production 
and scientific fields.

At the same time, today in Ukraine, there is no proper legal regulation, protection and recognition of the authors' rights to certain results of their intellectual activity including scientific discoveries and rationalization proposals despite the fact that these rights are recognized by the Civil Code of Ukraine, where it is stated that these rights are protected by the relevant laws [2].

The author proposes a method for improving the mechanism of legal protection of intellectual property for a scientific discovery, business method or rationalization proposal, which, by their definition, have materials that contain signs of patentable solutions. Therefore, at the stage of consideration of application materials, it is proposed to reveal a protectable part in each of them followed by the procedure for its patenting in accordance with the procedure established by the current legislation. In this case, it is necessary to carry out obligatory state registration of the said objects for securing appropriate priority for them.

\section{Results and their discussion}

The model of innovative development chosen by Ukraine requires implementation of measures aimed at stimulation and protection of intellectual property objects and development of such improved legislative basis in this sphere, which would allow not only to preserve existing scientific potential but also to ensure proper protection for the rights of creators of such objects.

These issues were studied by such scholars, researchers and lawyers as Yu.M. Kapitsa, O.S. Ioffe, F.K. Klimenko, E.A. Kozhina, O.V. Kokhanovskaya, N.S. Kuznetsova, R.A. Maidanik, I.E. Mamiofa, N. Nenovsky, A.M. Pavlov, V.I. Ryasentsev, V.I. Serebrovsky, R.O. Stefanchuk, I.Ya. Heifets, G.O. Androschuk, O.B. Butnik-Siversky, M. Kikuchi, N. M. Mironenko S.A. Petrenko, O.A. Podoprigora, P. Samuelson, O.P. Sergeyev and others in their scientific works.

In order to determine legal essence and trends of further legal protection of intellectual activity results, we consider it necessary to dwell on consideration of each of the objects separately: scientific discoveries, rationalization proposals and business methods.

Thus, according to Article 457 of the Civil Code of Ukraine, it is recognized that scientific discovery means establishing of such previously unknown, though objectively existing laws, properties and phenomena of the material world, which radically change level of scientific knowledge [2]. Since Article 458 of the Civil Code of Ukraine stresses that the right to scientific discovery must be protected in the framework of the relevant law, a draft of such a law was submitted to the Verkhovna Rada of Ukraine and adopted at the first reading [3]. The draft secured personal non-proprietary rights for the author of discovery, such as the right to name, the right to authorship, giving the author's own name to his/her discovery, and others. Besides, a certain procedure was established for conducting an expert examination and recognition of discoveries at the state level. However, for many reasons, the draft law, unfortunately, did not come into force. Accordingly, the problem of protecting the scientific discoveries and rights of their authors still remains open and is realized only on a voluntary basis. At the same time, scientific discoveries are the basis for new trends in the development of science and technology and creation of fundamentally new technical (patentable) solutions based on these discoveries in numerous inventions. In addition, the scientific discoveries have technical and technological potential featuring great practical value and significance for their authors [4].

Another result of intellectual activity is rationalization proposals. Article 481 of the Civil Code of Ukraine defines rationalization proposal as a proposal recognized by a legal entity and contained some technological (technical) or organizational solutions for certain 
field of activity, and determines that the object of the rationalization proposal may be a material object or process. Rationalization proposal can be useful for the enterprise, in which it is filed, if its use enables this enterprise to increase its economic efficiency or to obtain some other positive effects. That is, the basis lies in comparison between the result, which should be obtained due to the use of appropriate solution, with the result, which has been already obtained by the enterprise while fulfilling the needed task. In this case, positive economic effect can be manifested as increase of labor productivity, saving of resources used, upgrade of certain product quality, and so on. Rationalization proposals, due to their availability and mass utilization, can give even greater economic effect than inventions. As an example the American corporation "IBM" can be mentioned. For ten years, this company paid $\$ 60$ million to its employees for effective rationalization proposals, and the implementation of these proposals allowed the company to save more than $\$ 300$ million [5].

Business method is relatively new for the Ukrainian intellectual property legislation. However, the experience of such foreign countries as the United States of America and Japan shows that, under certain conditions, obtaining a patent for any business method is possible. It is known that the Patent Office of the United States granted patents, which were related to computer systems for processing and control of bank accounts, the methods of mathematical analysis of electrocardiographic signals, processing of seismic signals, navigation systems [6].

In terms of the requirements of the Ukrainian current legislation in the field of intellectual property, we consider that the object closest to the business method is a way. In this case, the way is recognized as an action or set of actions that are performed in relation to the products and other material objects with the help of at least one product and aimed at achieving a specific technical result. In particular, a way can be manufacture, processing, recycling of the product and control of the product quality, data, diagnosing, treatment [7]. In the Ukrainian current patent practice, cases are known when patents were granted precisely for the method, in particular, in the form of "the way of constructing the information system for personal management" [8].

Determination and embodiment of promising trends of further protection of intellectual property, development of improved legislative basis in this area is possible through introducing of a mechanism for improving the legal protection of certain results of intellectual and creative activity [9].

One of the key factors, which today impedes improvement of legal protection of intellectual property in Ukraine, is absence of any unified approach, which would ensure legal protection for those results of creative and intellectual activity and intellectual property objects in the field of scientific and technical activities, which contain signs of protectable solutions subject to patenting.

Today, conditions of the service market require legal securing of exclusive rights for those people who create scientific and technical achievements, competitive products, new technologies. For the most part, this is provided by the patent form of protection of numerous results of creative activity. The patent system promotes technological development by stimulating the creation of new technologies and providing conditions for their industrial application [10]. Obtaining by the author a security document in the form of the patent for his/her object of intellectual property means not only the actual secure of his/her exclusive rights to this object for its further commercial use. It also provides the author with opportunity to cover his/her own expenditures spent for researches, obtain some protection against illegal use of his/her achievement by any third parties, enrich domestic science with his/her own developments and create new opportunities for the country competitiveness on the international scene.

It should be noted that mechanism of patenting any industrial property objects, in 
particular, inventions, useful models and industrial prototypes, is well correlated with the approach to improving legal protection of scientific discovery, rationalization proposal and business method. As experience in protecting documents (patents) for the inventions and useful models obtained during the years of the Ukrainian independence evidences, the approach well and successfully reflects realization of technical (technological) result implementation from the stage of filing an application for the invention (useful model) to the stage of issuing a security document (patent).

It is the very classic patenting mechanism that is today most suitable for Ukraine for developing innovative relations, which, at a sufficiently high level, makes it possible to secure, preserve and further protect any industrial property objects.

Reasonability of this approach is confirmed by the long patenting experience in this field in our country, as well as in other countries, where the patent institute has been successfully used for several decades for patenting numerous intellectual property objects, and presents an evidence of the fact that it can be used for further improvement of legal protection of intellectual property.

That is why we are of the opinion that the improved mechanism of legal protection of the said objects may be as follows. Each of the objects of intellectual property - either scientific discovery, or rationalization proposal, or business method - has, by its definition, a part, containing signs of patentable solutions. Therefore, it is proposed, at the stage of the application considering, to reveal in each of these objects the protectable part, which is subject to legal protection followed by the procedure of its patenting in accordance with the procedure established by the current legislation.

For example, in terms of scientific discovery, it is underlined that any scientific discovery should contain theoretical, experimental and practical data, which substantiate the essence of the claimed scientific solution. It is further determined that special attention should be focused on the part with practical application of the scientific discovery results since it contains materials that are subject to legal protection and make this scientific discovery protectable. It is these discoveries that allow, for the shortest possible time, to implement the new technological (technical) solutions that are realized through the inventions. A similar approach can be applied to business methods and even to rationalization proposals.

Regarding the legal protection of the business method, it is proposed to reveal in the application materials its protectable part, which is claimed as "the way". If the application meets the declared criteria of protectability, it can be properly filed in order to obtain a protection document from the government agency.

The appropriateness of this approach is confirmed by the positive long-term implementation of fundamental and applied researches in the field of mining science, the results of which have been recognized as scientific discoveries.

Institute of Geotechnical Mechanics named by N. Poljakov of National Academy of Sciences of Ukraine established a previously unknown law of the stressed rock destruction during development of the coal deposits [11].

The essence of the law is that in the course of performing mining operations under certain conditions, destruction of the rock mass is activated even at very weak and lowenergy impacts.

Registration of this scientific discovery allowed officially securing priority of the country in terms of new scientific trend in the field of rock mechanics - deformation and destruction of outside rocks and massifs.

As a result, fundamentally new technologies and machines have been designed, which allow to control releasing of the rock massif potential energy and to use this energy for useful work. Today, the technologies and equipment protected by tens of certificates of authorship and patents are still successfully used for coal mining and coal-mine methane 
capturing in difficult geological conditions.

\section{Conclusions}

It is concluded that at the present stage, due to the development of innovative relations and integration of Ukraine into the European research domain, new approaches and methods are constantly being sought for improving the mechanism of legal protection of intellectual property. It is proposed to improve legal protection of intellectual activity results, which are obtained in scientific and technological spheres and directly influence the innovative development of the country. Reasonability of introducing such improvement of legal protection is shown on the example of such objects as scientific discoveries, business methods and rationalization proposals.

\section{References}

1. Convention Establishing the World Intellectual Property Organization. http://zakon2.rada.gov.ua/laws/show/995_169

2. Tsivilnii Kodeks Ukrayini. (2018). Kyiv: Skhola

3. Pro okhoronu prav na naukovi vidkrittya: proekt Zakonu Ukrayini vid 14.12.2004., No 6414. http:// zakon.rada.gov.ua

4. Bulat Ye.A. (2015). Some aspects of legal protection of scientific discovery in the context of patenting, Porivnyalne analitichne pravo, 6, 75-77

5. Svyatotskiy, O.D., Kraynev, P.P., Prakhov, B.H. (2004). Intellectual property right of rationalization proposal. Kyiv: InYure

6. Patent Protection for Software and business Methods in the United States. http://www.innovaccess.eu/sites/default/files/patentprotectionforsoftwareinusa_000000 6102_00.xml.pdf

7. Pravila skladannya i podannya zayavki na vinakhid i zayavki na korisnu model vid 22.01.2001, (22). http://zakon3.rada.gov.ua/laws/show/z0173-01

8. Serkov, O.A., Churuymov, H.I., Logvinenko, M.P., Pevnev, V.Ya. (2006), Sposib pobudovi informatsiynoyi sistemi dla keruvannya personalom. Patent No 14255 , Ukraine

9. Bulat Y. (2015). Some aspects of legal protection of business methods, Jurnalul juridicnational: Teorie si Practica, 5-2 (15), 38-40

10. Plotnikova N.V. (2003). Osnovi patentovedeniya: uchebnoye posobiye. Chelyabinsk: UYurHu

11. Poturayev, V.N., Zorin, A.N., Vinogradov, V.V., Bulat, A.P. (2008), Zakonomernost razrusheniya predelno napryazennykh gornikh porod pri slabikh vozdeystviyakh: nauchnoe otkritiye 1. Nauchnie otkritiya uchenykh SNG: kratkiy spravochnic. Dnipropetrovsk: Novaya ideologiya 